\title{
The Cottonwood Lake Study Area, a Long-Term Wetland Ecosystem Monitoring Site
}

The Cottonwood Lake study area (fig. 1) is located in Stutsman County, North Dakota, about 35 miles northwest of the U.S. Geological Survey (USGS) Northern Prairie Wildlife Research Center near Jamestown. Wetlands in the study area occupy depressions in a landscape that were formed by glacial processes during the Pleistocene epoch. These wetlands, known as prairie potholes in the United States and sloughs in Canada, are important breeding areas for migratory waterfowl and other wetland-dependent wildlife. The Cottonwood Lake study area is one of only three long-term wetland ecosystem monitoring sites in the prairie pothole region of North America; the other two are Orchid Meadows in South Dakota and St. Denis in Saskatchewan. Of the three, Cottonwood Lake has, by far, the longest continuous data-collection record. Research was initiated at the study area in 1966, and intensive investigations of the hydrology, chemistry, and biology of prairie pothole wetlands continue at the site today.

\section{Research Focus}

Long-term research at the Cottonwood Lake Study Area (CLSA), conducted by the U.S. Geological Survey (USGS), has focused on determining the effects of climate and groundwater on surface-water levels (fig. 2), the hydrological effects on wetland water chemistry, and the combined effects of climate, hydrology, and water chemistry on plant and animal communities of prairie pothole wetlands. Resultant datasets have contributed greatly to current investigations into the study of wetland ecosystems and facilitate responsiveness in addressing contemporary questions of importance to society. As an example, a study on greenhouse gas emissions from prairie pothole wetlands was recently initiated at the CLSA to explore the contribution of prairie pothole wetlands to climate change and to identify potential mitigation strategies. The period of record covered by the CLSA datasets (1978-2011) includes a 5-year drought comparable to that of the dustbowl era of the 1930s and a period of abundant precipitation that likely has not been equaled during the preceding 500 years. These dynamic changes in climate occurred for the period of record provide unique opportunities to examine changes in water chemistry, hydroperiod, and biotic communities (including plants, aquatic invertebrates, amphibians, microorganisms, and avifauna) that would not be possible without the availability of long-term data. Additionally, the availability of historical long-term data from the CLSA has been instrumental in attracting cooperators, partners, and significant funding (primarily from the U.S. Department of Agriculture) to further investigate the potential effects of climate change and resultant land-use change on a diverse suite of ecosystem services. The understanding of the interrelation of hydrological, chemical, and biological processes revealed by the interdisciplinary research conducted at the CLSA provides the scientific foundation that is being used in the development of an integrated landscape modeling and monitoring system that will allow managers and decision makers to better understand the outcomes of various management actions. Current objectives of the study are (1) conduct investigations into the effects of climate change on wetland ecosystems through the use of historical datasets, (2) provide baseline long-term monitoring data for the development of process-based computer models to simulate the functions of prairie ecosystems under various climate-change scenarios, and (3) continue collection of data related to the long-term monitoring of climate, hydrology, water chemistry, and biotic communities of this prairie wetland complex to ensure relevance of the site's long-term data in meeting future research needs.

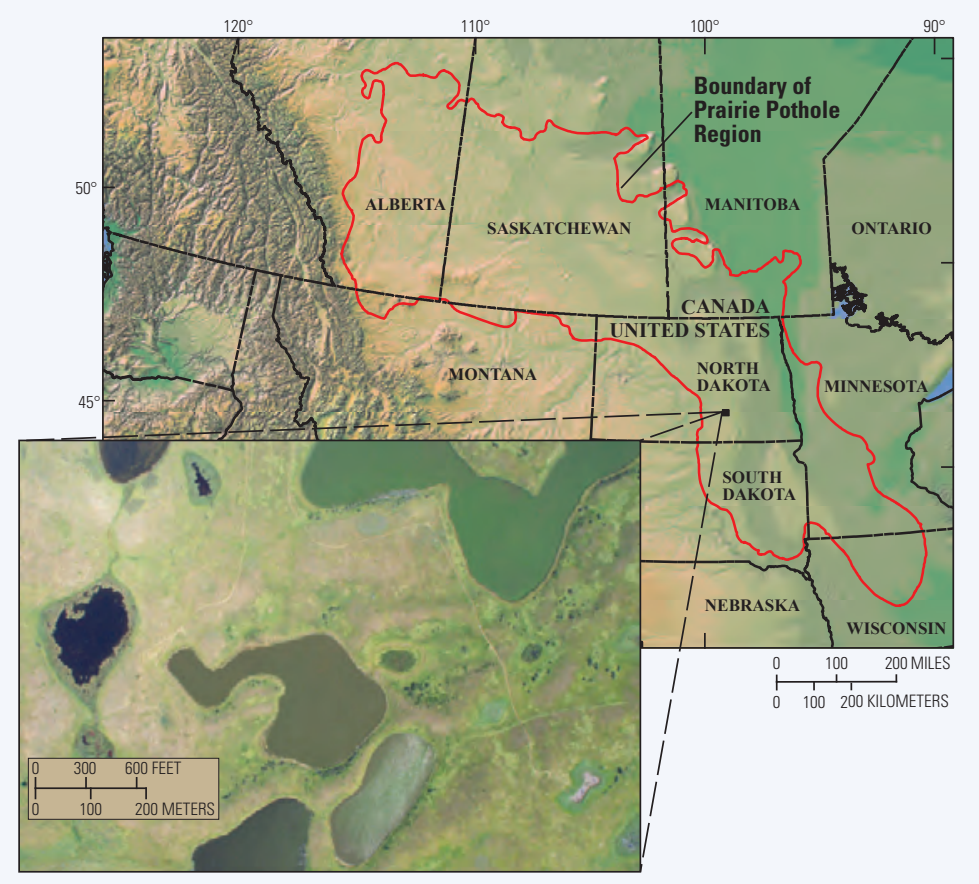

Figure 1. Location and inset photograph of the Cottonwood Lake study area, North Dakota. 
Hydrology-Sixty water-table surficial wells and 17 staff gages have been installed at CLSA to define the water-table configuration and the vertical hydrologic-head gradient within the wetland and groundwater system.

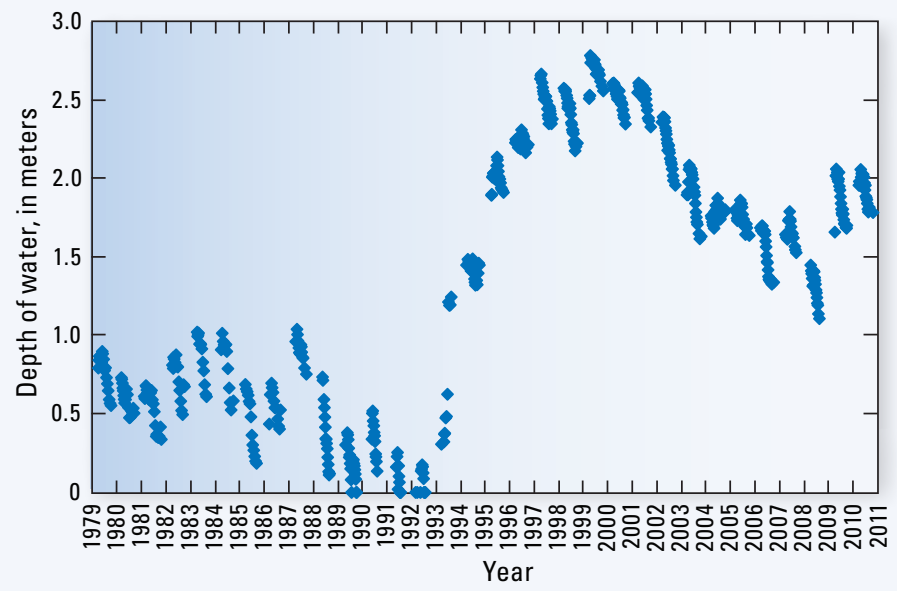

Figure 2. Interannual variation in water levels of a semipermanent wetland at Cottonwood Lake study srea.

Water chemistry-Cations and anions, major nutrients, $\mathrm{pH}$, and specific conductivity are measured in water samples collected from wetlands at monthly intervals.

Climate-Precipitation is measured with a constantrecording tipping-bucket rain gage and a nonrecording rain and snow gage. Air temperature, relative humidity, surface-water temperature, and wind speed are constantly recorded during the open-water season to calculate evaporation rates. Snow depths are measured periodically throughout the winter.

Plants-Changes in wetland vegetative zones are documented with aerial photographs taken of each wetland during

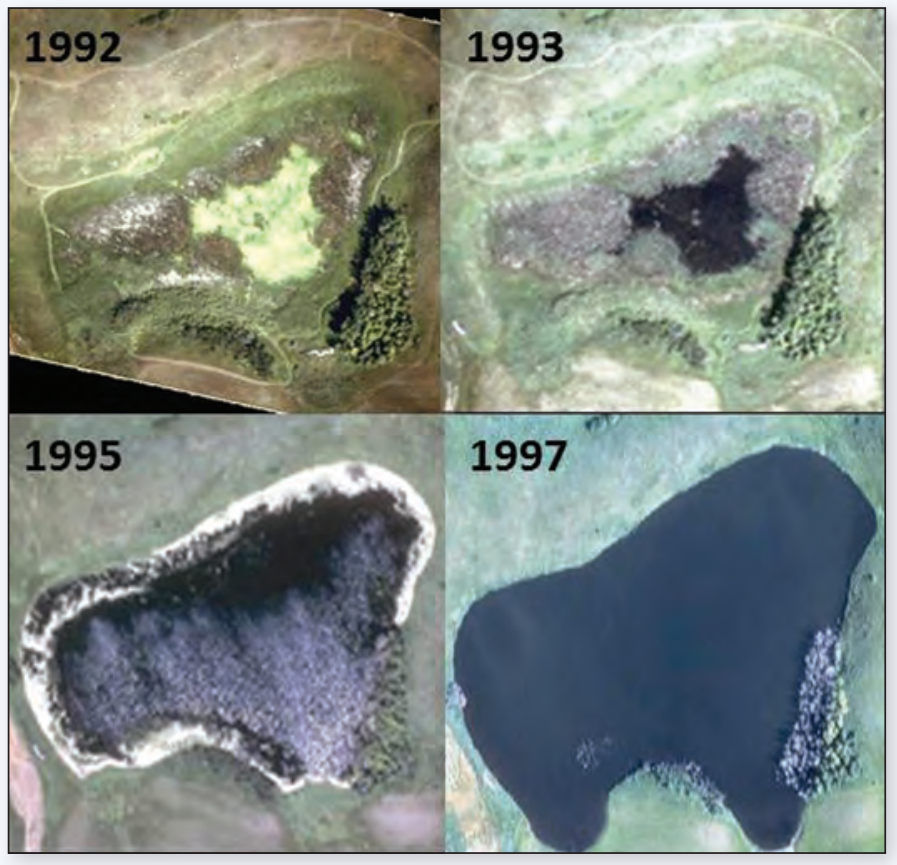

Figure 3. Aerial photographs of CLSA wetland P7 showing interannual variation of vegetation zones from a period of drought (1992) to significant flooding (1997). midsummer (fig. 3). Aerial photographs are georeferenced, and major vegetative zones are delineated, using geographic information systems software. Species composition of plant communities is determined from surveys conducted at the peak of the growing season.

Aquatic macroinvertebrates-Samples are collected monthly from all wetlands. Vertically oriented funnel traps and benthic corers are used to assess invertebrate densities and biomass. Sampling is stratified to provide separate estimates for all major vegetative zones of each wetland.

Amphibians-Tiger salamanders (Ambystoma tigrinum) and frogs are sampled 1 week each month from May to September in each wetland using amphibian funnel traps placed in the central zones of wetlands. The data collected consist of number of individuals, sex, and developmental stage (larval, adult) of all amphibians captured.

Birds-Monthly bird counts-Birds are censused in each wetland at monthly intervals from April to September. For each species, sex and number of individuals in each wetland are recorded.

Breeding bird surveys-Surveys are conducted daily for each wetland from late May to early June (12 surveys total). Data consist of the number of territories for each species (fig. 4) associated with individual wetland basins and are used as a yearly measurement of breeding bird response to CLSA wetlands.

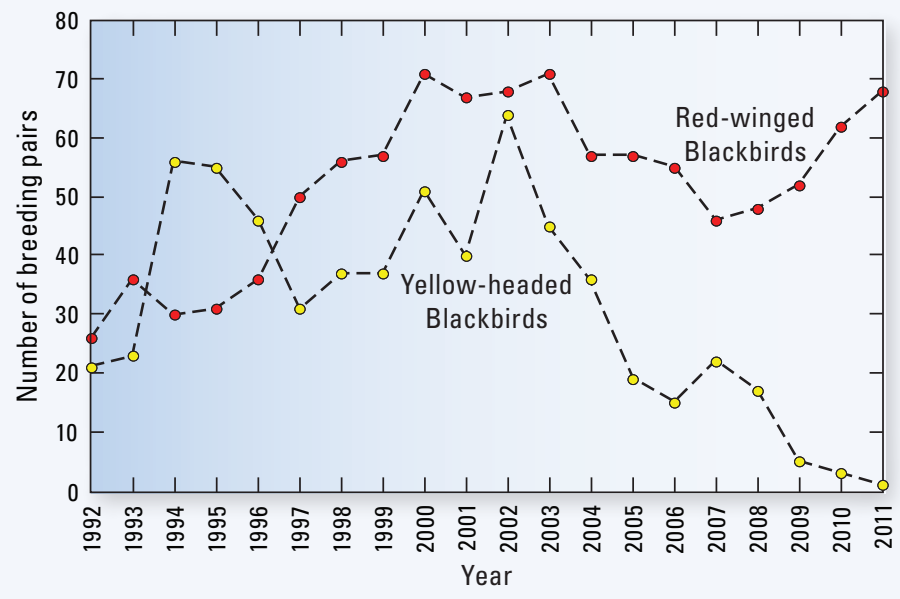

Figure 4. Red-winged Blackbird (Agelaius phoeniceus) and Yellow-headed Blackbird (Xanthocephalus xanthocephalus) breeding pairs, 1992-2011.

A complete list of more than 190 scientific publications, dissertations, theses, and presentations resulting from investigations at the CLSA can be found at www.npwrc.usgs. gov/cottonwood.html.

For more information, contact: Ned (Chip) Euliss, Jr., or David M. Mushet Northern Prairie Wildlife Research Center 8711 37th Street SE, Jamestown, ND 58401

Telephone: (Euliss): 701-253-5564 (Mushet): 701-253-5558

Email: (Euliss): ceuliss@usgs.gov (Mushet): dmushet@usgs.gov 